\title{
'n Transformerende Bybelreis om die waarheid van die Skrif vir vandag te ontsluit
}

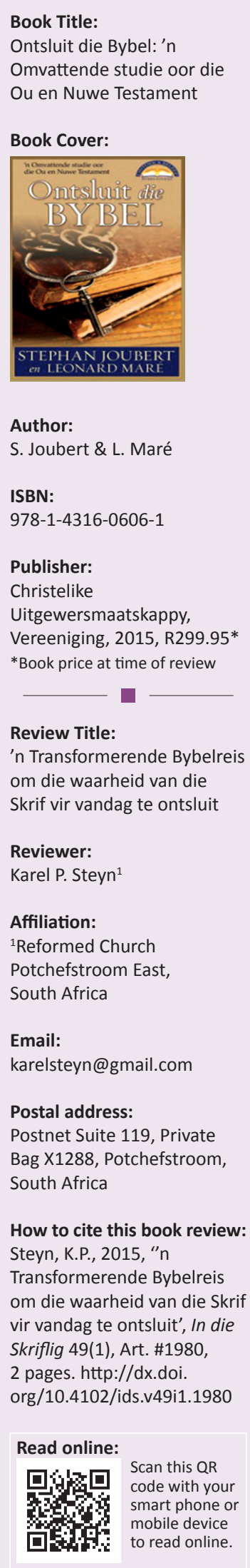

In Ontsluit die Bybel: ' $n$ Omvattende studie oor die Ou en Nuwe Testament, bied Stephan Joubert en Leonard Maré 'n praktiese, populêr-wetenskaplike hulpmiddel aan die ernstige Bybelstudent. Hierdie publikasie is werklik, in die woorde van die skrywers, '...'n Bybelskool in boekvorm ... 'n transformerende Bybelreis' (bl. 17).

Hierdie gedrukte Bybelskool bestaan uit drie dele wat telkens in 'n aantal Bybelreise opgedeel word om 'n totaal van 166 Bybelreise te beslaan. Elkeen van die drie dele van die publikasie, of die onderskeie kleiner afdelings in die groter dele van die publikasie, begin met 'n Bybelreis wat die agtergrond en konteks van daardie deel skets. Elkeen van hierdie drie inleidende Bybelreise skets dus die agtergrond waarteen die res van die Bybelreise in daardie betrokke deel of afdeling van die publikasie gelees moet word.

Deel 1, genaamd, Hoe verstaan en gebruik ons die Bybel reg?, handel oor die konteks van die ontvanger of die aanhoorder van die Bybelteks. In hierdie gedeelte van die boek word daar basiese eksegetiese en hermeneutiese vertrekpunte gebied, gesien in die lig van die verskillende stromings en teologiese strome wat daar tans binne die universele kerk en die wêreld heers. Die nood vir die kontekstuele verstaan van die Skrif word bepleit, asook die noodsaak van die verrekening van die openbaringshistoriese lyne wat regdeur die Skrif aangetref word. Verder word verskeie reformatoriese standpunte oor die inspirasie van die Skrif, die werking van die Heilige Gees in Skrifverklaring en die gesag van die Skrif in hierdie eerste gedeelte uitgestippel.

Deel 2 behandel die Ou Testament en word in drie kleiner gedeeltes verdeel, naamlik verhalende literatuur, wysheidsliteratuur en die profetiese boeke en dit beslaan Bybelreise 6-76. Elke boek van die Ou Testament word in hierdie gedeelte in breë trekke behandel. Telkens word die openbaringshistoriese lyne na die Nuwe Testament uitgewys. Elke Bybelreis bevat ook 'n aantal vrae wat die Bybelstudent begelei om die basiese eksegetiese en hermeneutiese vertrekpunte wat in Deel 1 neergepen is, toe te pas.

Deel 3 wat die Nuwe Testament behandel, beslaan Bybelreise 77-166 en behandel die Evangelies, die briewe en die ander literatuur van die Nuwe Testament in die volgorde wat dit in die Skrif voorkom. Elke boek van die Nuwe Testament word met 'n inleidende Bybelreis begin wat die konteks, die skrywer en die ontstaanswerklikheid van elke boek weergee. Elke Bybelreis bevat ook vrae waardeur die Bybelstudent begelei word om die eksegetiese en hermeneutiese vertrekpunte op die verskillende genres van die Nuwe Testament toe te pas.

Alhoewel die publikasie nie op volledigheid aanspraak maak nie, is dit tog opmerklik dat daar sekere openbaringshistoriese lyne is wat nie in hierdie publikasie aandag ontvang nie. Só is dit byvoorbeeld opvallend dat daar in Bybelreise 22 en 23, wat handel oor die lewe van Dawid volgens 1 en 2 Samuel, niks van die verbond wat God met Dawid opgerig het, vermeld word nie. Hier word dus 'n kritiese openbaringshistoriese lyn, wat 'n klimaks in die troonbestyging van Christus bereik, nie hanteer nie.

Alhoewel sommige teologiese begrippe in die teks gedefinieer word, sou 'n volledige woordelys 'n groot aanwins tot die publikasie gewees het. Die gebruik van tydlyne in die publikasie sou verder tot die duidelike uiteensetting van die konteks van die verskillende dele in die Skrif kon bydra asook van die openbaringshistoriese lyne wat in die publikasie bespreek word.

Van groot waarde in hierdie publikasie, is die beskrywing van die sosio-historiese konteks wat deurgaans aangetref word. Alhoewel Bybelreise 4 en 5 op 'n paar aspekte van die sosio-historiese konteks van die Nuwe Testament fokus, word daar regdeur die publikasie waardevolle insigte in die leefwêreld van die skrywers en die karakters gegee. 
In 'n era van relativisme en waar die gesag van die Skrif bevraagteken word, is hierdie publikasie van besondere waarde vir elke ernstige Bybelstudent. Alhoewel daar nie nuwe of oorspronklike perspektiewe op die
Skrifwaarhede gegee word nie, bied hierdie publikasie waardevolle gereedskap aan elke leser waarmee die waarheid van die Woord aan die dag gelê kan word - 'n ware transformerende Bybelreis! 